\title{
Improvement the Productivity and Quality of Pelargonium $\times$ hortorum L. Plants by Using Potassium Iodide Applications
}

\author{
Naema I. EL Sayed \\ Ornamental Plants and Landscape Gardening Research Department, Horticulture \\ Research Institute, Agriculture Research Centre, Cairo, Egypt.
}

\begin{abstract}
IODINE HAS considered as a trace beneficial element for higher plants and it has long been recognized as an important element environmentally. In order to study the effects of different application methods (foliar spray, soil application or foliar combined with soil application) of potassium iodide (KI) at 2, 4, 6 or $8 \mathrm{mg} \mathrm{L}^{-1}$ on vegetative growth and some physiological characteristics of Zonal pelargonium (Pelargonium $\times$ hortorum L.) plants, a pot experiment was carried out during 2017 and 2018 at AL Mansoura Horticulture Research Station, Horticulture Research Institute, Agriculture Research Center, Egypt. The study showed that generally all different applications had positive effects on the vegetative growth and inflorescence parameters except foliar application at $2 \mathrm{mg} \mathrm{L}^{-1}$ concentration. Soil application at 2, 4 or $6 \mathrm{mg} \mathrm{L}^{-1}$ showed the highest values of shoot length, number of branches and fresh and dry weight. Soil combined with foliar applications at $6 \mathrm{mg} \mathrm{L}^{-1}$ gave the highest number and neck length of inflorescences per plant. Additionally, the same application method at $4 \mathrm{mg} \mathrm{L}^{-1}$ resulted in the highest diameter of inflorescences.All used iodine treatments increased significantly nitrogen, phosphorus and total sugars in pelargonium plants over control while, the total polyphenols content of pelargonium plants was decreased in comparison to control plants. The results refer to the possibility of using $\mathrm{KI}$ as soil application for improved the productivity and quality of pelargonium plants.
\end{abstract}

Keywords: Pelargonium plants, Potassium iodide, Foliar application, Soil application, Inflorescence parameters.

\section{Introduction}

Zonal pelargonium (Pelargonium $\times$ hortorum L., family Geraniaceae) is a perennial evergreen, mostly grows naturally in tropical, subtropical and Mediterranean climates. Pelargonium is the most important summer flowering ornamental plant using in landscape design. It's extremely popular using as bedding plants in landscape, decoration of windows, balconies, terraces and roof gardens. Pelargonium plants were the most popular garden plants. Sales of garden plants increased in the Dutch market by $9.3 \%$ from 2016 to 2017 , and the pelargonium plants ranked sixth by 19 million units sold at 13 million euro (Flora Holland annual report, 2017). This arrangement indicates the great economic importance of the pelargonium plants in Europe. To maximize growth and quality of pelargonium, the fertilization during production is extremely important. So, the looking for low cost fertilizers is a must now.
Iodine (I) is a trace element and distributed into the atmosphere and land areas from the oceans which considered as the largest reservoirs of bioavailable iodine on the planet (Venturi, 2011). The second largest reservoir of iodine is the soil (Muramatsu and Yoshida, 1999). Iodine in the form of gas and aerosol is carried by the wind and rain to land areas, where it is found in soil mostly in two forms: iodide $\left(\mathrm{I}^{-}\right)$and iodate $\left(\mathrm{IO}_{3}^{-}\right)$(Medrano-Macías et al., 2016). In soil, iodine is spreaded in several ways: evaporate into the atmosphere by abiotic and biotic processes, fixed in soil and biomass, or backed to the oceans through water streams (Moreda-Piñeiro et al., 2011, Saunders et al., 2012 and Fuge \& Johnson, 2015). Iodine considered as non-essential element for higher plants, although all plants can assimilate it from soil. Iodine in humus and clay soils is fixed by organic substances and aluminium and iron oxides. So, the plants grown in the soils which contains organic matters have a low iodine content (Jopke et al., 1996).

Corresponding author: Naema I. EL Sayed, e-mail:naema.shalan62@gmail.com 
Iodide has considerable bioavailability for plants comparing with iodate (Whitehead, 1973). Iodine content in the plant significantly increased with increasing in iodine concentration and was up to five times higher with $\mathrm{I}^{-}$than with $\mathrm{IO}_{3}^{-}$(Voogt et al., 2010). Iodine treatment contributed to increase the $\mathrm{P}, \mathrm{K}$ and Ca contents of carrot roots (Smolen et al., 2011).

The highly cost of factorial fertilizers for production of ornamental plants led to search for low cost nutrition as an alternative. So, the aim of this study was to assess the influence of application methods with potassium iodide (KI) on production and quality of Zonal pelargonium.

\section{Materials and Methods}

Plant material and experimental design

A pot experiment was conducted at AL Mansoura Horticulture Research Station, Horticulture Research Institute, Agriculture Research Center, Egypt, during 2017 and 2018 seasons. Terminal cuttings $(8 \pm 1 \mathrm{~cm}$ long) were obtained from Zonal pelargonium (Pelargonium $\times$ hortorum L.), two years old, at $7^{\text {th }}$ January and planted in plastic pots $(15 \mathrm{~cm}$ in diameter $)$ filled with a mixture ofsand and clay soilat 2:1 vol.:vol.(a single cutting/pot). A random soil sample was collected from the soil mixture before the beginning of the treatments and was air-dried, ground and sieved over a $2 \mathrm{~mm}$-sieve. Physico-chemical properties were carried out as the following: distribution of particle size by using the pipette method as described by Dewis and Fertias (1970), electrical conductivity and the soil $\mathrm{pH}$ of saturated soil paste extract according to Jackson (1967) and Richards (1954). Data of soil analysis was presented in Table 1. Cuttings were transplanted at one month age into plastic pots $(25 \mathrm{~cm}$ in diameter) filled with the same soil mixture and remained till the end of the experiment. Plants were not received any fertilizers along the experimental period and watered once time a week during the initial three months of the experiment and 2 times a week during the late three months. The plants were grown under a semi-shade trellis over the experimental period. The experimental design was complete randomized block with three replicates.

\section{Potassium Iodide treatments}

Potassium iodide (KI) was purchased from Al-Gomhorya Pharmaceutical Company, Mansoura branch, Egypt. Plants were treated with $\mathrm{KI}$ in five times with one month intervals. The first addition of KI treatments was at $21^{\text {st }}$ day Egypt. J. Hort. Vol. 46, No.1 (2019) after planting cuttings by three methods: foliar spray, soil applicationor combined foliar with soil application at 4 concentrations: 2, 4, 6, and $8 \mathrm{mg} \mathrm{L}^{-1}$. Distilled water was used for preparing the KI solutions supplement with $0.02 \%$ Tween 20, (polyoxyethylenesorbitan monolaurate), as a surfactant to improve spreading and sticking properties. Plants treated with KI as spraying method were done manually by using spraying bottle until it flooded on the plants while plant treated as soil application were done by add a $100 \mathrm{ml} /$ pot of KI solutions as soil drench. The pot ground surface of spraying treatments was covered with foil paper to prevent any solution to drop to the soil. Control plants (zero KI concentrate) were sprayed with distilled water.

Vegetative parameters were measured at the end of the experiment (at 4 months after transplanting) and included: plant height, number of branches/plant, and shoot fresh and dry weights.

Inflorescences characteristics were begun to measure at the inflorescences stage after thirty days of transplanting, when at least two inflorescences were blooming. Inflorescences parameters were included: number of inflorescences/plant, diameter of inflorescences, and theinflorescences neck length. Inflorescences were counted every week until the end of the experiment and they were removed after falling approximately $70 \%$ of florets.

Physiological measurements were done at the end of the experiment. Randomly fully mature leaves were taken from three plants per replicate to estimate the total chlorophyll and carotenoids contents (mg/g fresh weight) according to Lichtenthaler and Wellburn (1983). Nitrogen, phosphorus and potassium were determined according to the Association of Official Analytical Chemists (A.0.A.C, 1990), Olsen and Sommers (1982) and Jackson (1967) respectively. Total sugars content was measured per gram dry weight according to Dubioset al. (1956). Total polyphenol contents (TPC) were determined using the FolinCiocalteu method according to $\mathrm{Li}$ et al.(2007), where, gallic acid was used as a standard and total polyphenols content were expressed as mg gallic per gram dry extract.

\section{Statistical analysis}

The data were analyzed by one-way ANOVA using the analysis of variance technique by means of CoStat Computer Software (Cohort, Berkeley, CA,USA). Mean values were compared by using 
TABLE 1. Physico-chemical properties of the experimental soil (averaged over two seasons).

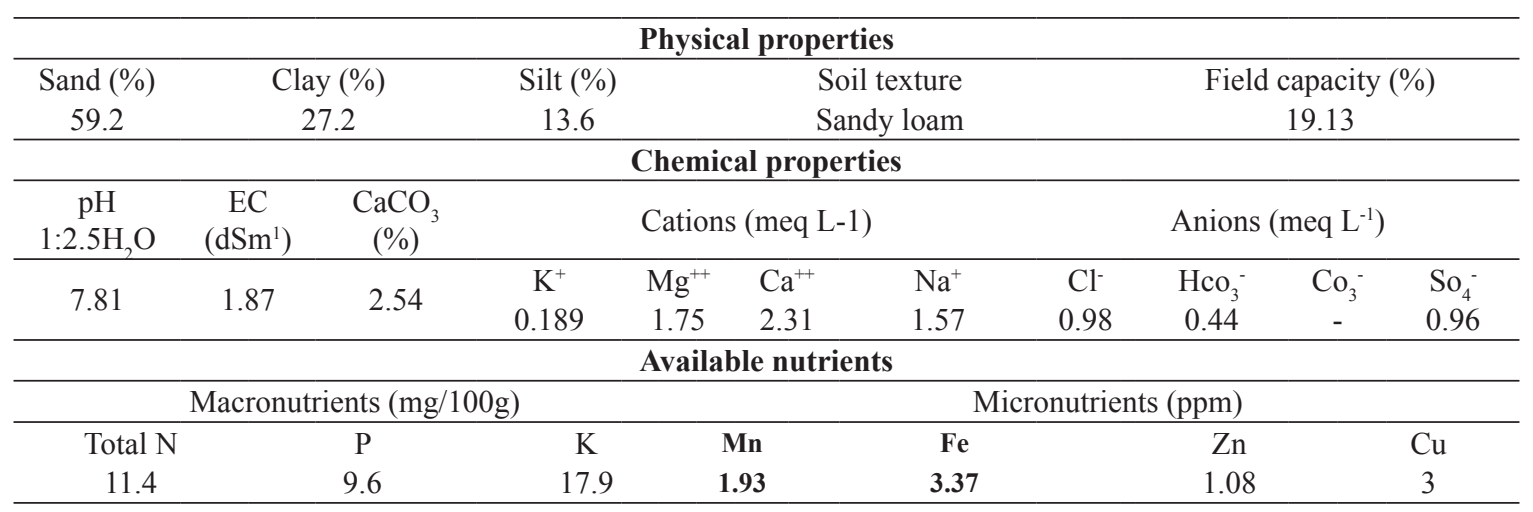

Duncan's multiple range test method as mentioned by Gomez and Gomez (1984) at least significance difference $(\mathrm{p} \leq 0.05)$.

\section{Results}

Vegetative growth parameters

From this investigation, it is clear that the impact of iodine in foliar, soil and foliar combined with soil application methods on vegetative growth traits had significanteffects in comparison to the control plants. The highest increasing in shoot length and fresh and dry weight were done by soil application at 4 and $6 \mathrm{mg} \mathrm{L}^{-1}$ in both seasons (Table 2). Additionally, the highest values in number of branches/plant were significantly

TABLE 2. Shoot length, number of branches/plant and fresh and dryweight/plant inPelargonium $\times$ hortorumas affected by different application methods and concentrationsof potassium iodide (KI) during the twoseasons (2017 and 2018).

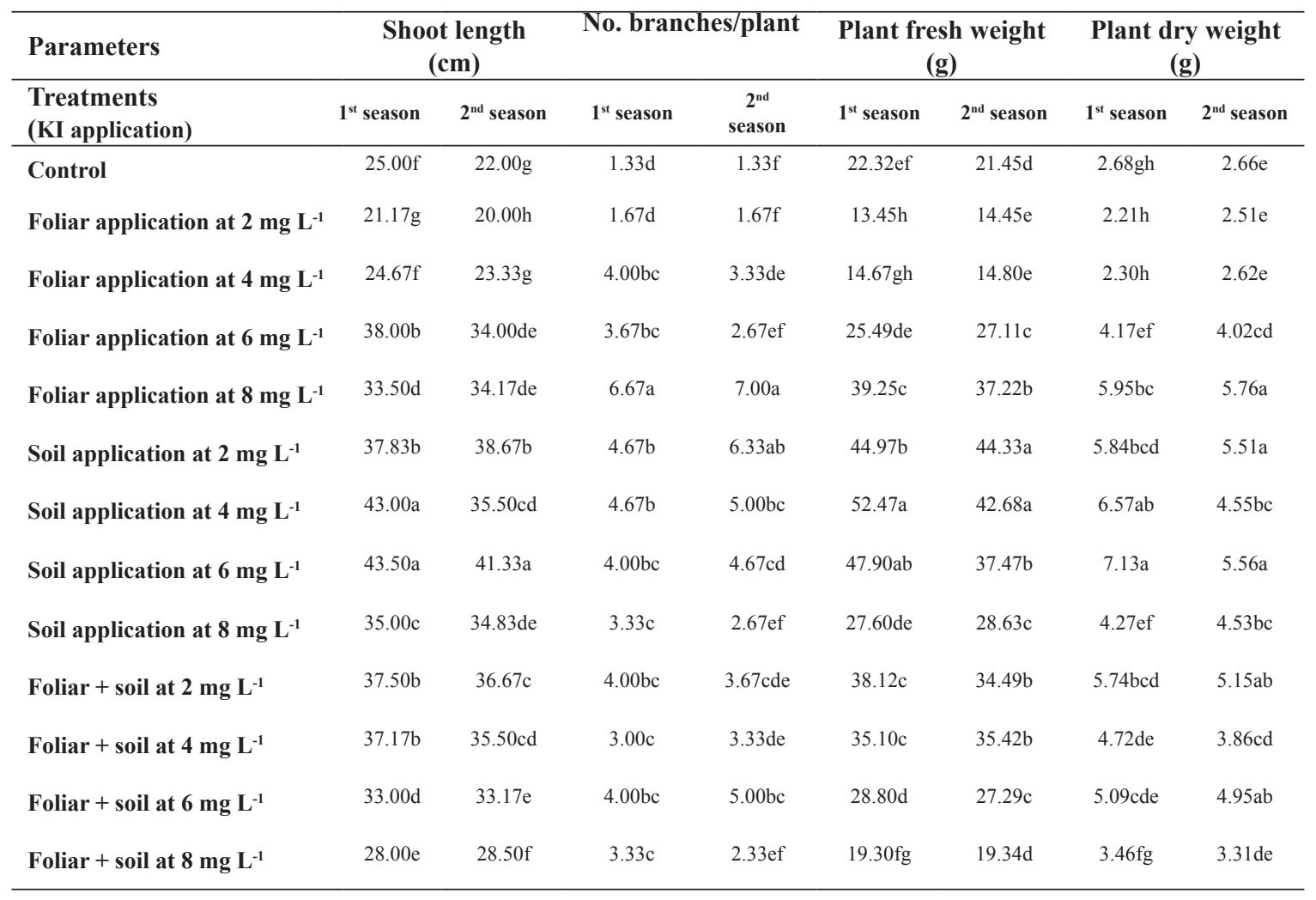

Mean values followed by the same letter in each column do not differ significantly at $\mathrm{P} \leq 0.05$ based onDuncan's multiple range test. 
recorded with foliar application at $8 \mathrm{mg} \mathrm{L}^{-1}(6.67$ and 7.00 branches/plant, respectively in both seasons).

Moreover, the combinations between foliar and soil application methods at concentrations of 2, 4 and $6 \mathrm{mg} \mathrm{L}^{-1}$ significantly increased the vegetative growth parameters comparing with the control plants. Foliar application with low concentration of KI (2 $\left.\mathrm{mg} \mathrm{L}^{-1}\right)$ significantly decreased the vegetative growth parameters in the both seasons.

\section{Inflorescence parameters}

In the context of presented data, it should be underlined that different application methodsof $\mathrm{KI}$ at all concentrations, generally, increased the number of Inflorescences and neck length and diameter of Inflorescences when compared to the control plants except, when plants sprayed with KI at 2 and $4 \mathrm{mg} \mathrm{L}-1$ which were not significantly during the two seasons (Table 3). Another exception, soil application with KI at 8 $\mathrm{mg}$ L-1or combined with foliar application at the same concentration did not affect the neck length and diameter of Inflorescences in comparison to the control plants. The highest number of Inflorescences was obtained by the combination between the foliar and soil application at 6 mg L-1 (17.67 and 17.00 Inflorescences/plant,

TABLE 3. Inflorescenceparametersin Pelargonium $\times$ hortorumas affected by different application methods and concentrations of potassium iodide (KI) during the two seasons (2017 and 2018).

\begin{tabular}{|c|c|c|c|c|c|c|}
\hline \multirow{2}{*}{$\begin{array}{l}\text { Parameters } \\
\text { Treatments (KI application) }\end{array}$} & \multicolumn{2}{|c|}{$\begin{array}{c}\text { No. inflorescences } \\
\text { /plant }\end{array}$} & \multicolumn{2}{|c|}{$\begin{array}{c}\text { Inflorescence } \\
\text { neck length }(\mathrm{cm})\end{array}$} & \multicolumn{2}{|c|}{$\begin{array}{l}\text { Inflorescence } \\
\text { diameter }(\mathrm{cm})\end{array}$} \\
\hline & $1^{\text {st }}$ season & $2^{\text {nd }}$ season & $1^{\text {st }}$ season & $2^{\text {nd }}$ season & $1^{\text {st }}$ season & $2^{\text {nd }}$ season \\
\hline Control & $7.00 \mathrm{~g}$ & $7.67 \mathrm{ef}$ & $8.40 \mathrm{f}$ & $8.73 \mathrm{~g}$ & $6.20 \mathrm{f}$ & $6.00 \mathrm{ef}$ \\
\hline Foliar application at $2 \mathrm{mg} \mathrm{L}^{-1}$ & $7.00 \mathrm{~g}$ & $6.33 f$ & $7.10 \mathrm{~h}$ & $7.60 \mathrm{~h}$ & $5.60 \mathrm{gh}$ & $6.23 \mathrm{def}$ \\
\hline Foliar application at $4 \mathrm{mg} \mathrm{L}^{-1}$ & $7.00 \mathrm{~g}$ & $8.33 \mathrm{e}$ & $8.13 \mathrm{fg}$ & $7.10 \mathrm{i}$ & $6.80 \mathrm{e}$ & $6.27 \mathrm{def}$ \\
\hline Foliar application at $6 \mathrm{mg} \mathrm{L}^{-1}$ & $12.00 \mathrm{de}$ & $11.0 \mathrm{~d}$ & $12.50 \mathrm{c}$ & $10.23 \mathrm{f}$ & $7.60 \mathrm{~d}$ & $6.50 \mathrm{de}$ \\
\hline Foliar application at $8 \mathrm{mg} \mathrm{L}^{-1}$ & $11.00 \mathrm{ef}$ & $12.33 \mathrm{bcd}$ & $10.50 \mathrm{e}$ & $10.00 \mathrm{f}$ & $9.00 \mathrm{~b}$ & $8.83 b$ \\
\hline Soil application at $2 \mathrm{mg} \mathrm{L}^{-1}$ & $15.00 \mathrm{~b}$ & $16.33 \mathrm{a}$ & $15.00 \mathrm{~b}$ & $14.00 \mathrm{c}$ & $9.00 \mathrm{~b}$ & $10.00 \mathrm{a}$ \\
\hline Soil application at $4 \mathrm{mg} \mathrm{L}^{-1}$ & $14.00 \mathrm{bc}$ & $12.67 \mathrm{bcd}$ & $16.00 \mathrm{a}$ & $14.37 \mathrm{bc}$ & $7.00 \mathrm{e}$ & $6.60 \mathrm{~d}$ \\
\hline Soil application at $6 \mathrm{mg} \mathrm{L}^{-1}$ & $14.00 \mathrm{bc}$ & $14.00 \mathrm{~b}$ & $12.17 \mathrm{c}$ & $11.00 \mathrm{e}$ & $8.50 \mathrm{c}$ & $8.00 \mathrm{c}$ \\
\hline Soil application at $8 \mathrm{mg} \mathrm{L}^{-1}$ & $10.00 \mathrm{f}$ & $11.33 \mathrm{~d}$ & $6.00 \mathrm{i}$ & $6.80 \mathrm{i}$ & $6.00 \mathrm{fg}$ & $5.40 \mathrm{~g}$ \\
\hline Foliar + soil at $2 \mathrm{mg} \mathrm{L}^{-1}$ & $15.00 \mathrm{~b}$ & $13.67 \mathrm{bc}$ & $11.50 \mathrm{~d}$ & $15.50 \mathrm{a}$ & $7.00 \mathrm{e}$ & $8.00 \mathrm{c}$ \\
\hline Foliar + soil at $4 \mathrm{mg} \mathrm{L}^{-1}$ & $8.00 \mathrm{~g}$ & $8.00 \mathrm{ef}$ & $15.00 \mathrm{~b}$ & $13.00 \mathrm{~d}$ & $10.00 \mathrm{a}$ & $8.50 \mathrm{bc}$ \\
\hline Foliar + soil at $6 \mathrm{mg} \mathrm{L}^{-1}$ & $17.67 \mathrm{a}$ & $17.00 \mathrm{a}$ & $16.00 \mathrm{a}$ & $14.60 \mathrm{~b}$ & $8.00 \mathrm{~d}$ & $8.00 \mathrm{c}$ \\
\hline Foliar + soil at $8 \mathrm{mg} \mathrm{L}^{-1}$ & $13.00 \mathrm{~cd}$ & $12.00 \mathrm{~cd}$ & $7.63 \mathrm{gh}$ & $7.90 \mathrm{~h}$ & $5.50 \mathrm{~h}$ & $5.77 \mathrm{fg}$ \\
\hline
\end{tabular}

Mean values followed by the same letter in each column do not differ significantly at $\mathrm{P} \leq 0.05$ based on Duncan's multiple range test.

respectively in both seasons). Moreover, the largest Inflorescence diameter was resulted from the combination between spraying plants and soil application with $\mathrm{KI}$ at $4 \mathrm{mg}$ L-1 concentration.

\section{Physiological parameters}

Effects of KI applications on total chlorophyll and carotenoid contents

Data in Table 4, evidently, reveal a variance of effects of KI at all concentrations and at all application methods on total chlorophyll content of pelargonium plants. It is clearly that plants received $\mathrm{KI}$ at $8 \mathrm{mg} \mathrm{L}^{-1}$ as foliar application and at 4 or $8 \mathrm{mg} \mathrm{L}^{-1}$ as soil application, were increased in total chlorophyll contents. The lowest value of total chlorophyll was induced with KI foliar spray at $6 \mathrm{mg} \mathrm{L}^{-1}$. Concerning the effect of KI application on carotenoids content, data in 
TABLE 4. Total chlorophyll and carotenoids $\left(\mathrm{mg} \mathrm{g}^{-1}\right.$ fresh weight) in Pelargonium $\times$ Hortorumas affected by different application methods and concentrations of potassium iodide (KI) during the two seasons (2017 and 2018).

\begin{tabular}{|c|c|c|c|c|}
\hline \multirow{2}{*}{$\begin{array}{l}\text { Parameters } \\
\text { Treatments (KI application) }\end{array}$} & \multicolumn{2}{|c|}{$\begin{array}{c}\text { Total chlorophyll } \\
\text { (mg g } \mathbf{g}^{-1} \text { fresh weight) }\end{array}$} & \multicolumn{2}{|c|}{$\begin{array}{l}\text { Total carotenoids } \\
\text { ( } \mathrm{mg} \mathrm{g}^{-1} \text { fresh weight) }\end{array}$} \\
\hline & $1^{\text {st }}$ season & $2^{\text {nd }}$ season & $1^{\text {st }}$ season & $2^{\text {nd }}$ season \\
\hline Control & $1.49 \mathrm{c}$ & $1.64 \mathrm{efg}$ & $0.027 \mathrm{e}$ & $0.028 \mathrm{de}$ \\
\hline Foliar application at $2 \mathrm{mg} \mathrm{L}^{-1}$ & $1.24 \mathrm{~d}$ & $1.51 \mathrm{~g}$ & $0.034 \mathrm{de}$ & $0.038 \mathrm{c}$ \\
\hline Foliar application at $4 \mathrm{mg} \mathrm{L}^{-1}$ & $1.75 b$ & $1.75 \mathrm{de}$ & $0.059 \mathrm{ab}$ & $0.032 \mathrm{cde}$ \\
\hline Foliar application at $6 \mathrm{mg} \mathrm{L}^{-1}$ & $1.53 \mathrm{c}$ & $1.56 \mathrm{fg}$ & $0.048 \mathrm{bcd}$ & $0.034 \mathrm{~cd}$ \\
\hline Foliar application at $8 \mathrm{mg} \mathrm{L}^{-1}$ & $2.19 \mathrm{a}$ & $2.02 \mathrm{ab}$ & $0.027 \mathrm{e}$ & $0.025 \mathrm{e}$ \\
\hline Soil application at $2 \mathrm{mg} \mathrm{L}^{-1}$ & $1.61 \mathrm{bc}$ & $1.80 \mathrm{cde}$ & $0.049 b c$ & $0.034 \mathrm{~cd}$ \\
\hline Soil application at $4 \mathrm{mg} \mathrm{L}^{-1}$ & $2.22 \mathrm{a}$ & $1.91 \mathrm{bcd}$ & $0.033 \mathrm{e}$ & $0.027 \mathrm{de}$ \\
\hline Soil application at $6 \mathrm{mg} \mathrm{L}^{-1}$ & $2.36 \mathrm{a}$ & $2.11 \mathrm{a}$ & $0.027 \mathrm{e}$ & $0.034 \mathrm{~cd}$ \\
\hline Soil application at $8 \mathrm{mg} \mathrm{L}^{-1}$ & $1.55 \mathrm{bc}$ & $1.69 \mathrm{ef}$ & $0.071 \mathrm{a}$ & $0.065 \mathrm{a}$ \\
\hline Foliar + soil at $2 \mathrm{mg} \mathrm{L}^{-1}$ & $1.64 \mathrm{bc}$ & $1.96 \mathrm{abc}$ & $0.064 \mathrm{a}$ & $0.037 \mathrm{c}$ \\
\hline Foliar + soil at $4 \mathrm{mg} \mathrm{L}^{-1}$ & $1.66 \mathrm{bc}$ & $1.51 \mathrm{~g}$ & $0.058 \mathrm{ab}$ & $0.053 b$ \\
\hline Foliar + soil at $6 \mathrm{mg} \mathrm{L}^{-1}$ & $1.74 b$ & $1.81 \mathrm{cde}$ & $0.036 \mathrm{cde}$ & $0.048 b$ \\
\hline Foliar + soil at $8 \mathrm{mg} \mathrm{L}^{-1}$ & $1.54 \mathrm{c}$ & $1.79 \mathrm{cde}$ & $0.041 \mathrm{cde}$ & $0.050 \mathrm{~b}$ \\
\hline
\end{tabular}

Mean values followed by the same letter in each column do not differ significantly at $\mathrm{P} \leq 0.05$ based on Duncan's multiplerange test.

Table 4 reveal that plants treated with all KI treatments led to increase the carotenoids content comparing to the control plants except that the $8 p p m$ concentration as foliar or soil application were not significant.

Effects of KI applications on nitrogen, phosphorus and potassium contents

Regarding the effect of treated plants with $\mathrm{KI}$ on $\mathrm{N}, \mathrm{P}$ and $\mathrm{K}$ contents, Table 5 shows that $\mathrm{KI}$ application methods at all concentrations, in general, led to greatly increase in $\mathrm{N}$ and $\mathrm{P}$ elements concentration in pelargonium shoots. Spraying plant at $6 \mathrm{mg} \mathrm{L}^{-1}$ gave the highest nitrogen percentage $(2.709 \%$ \& $2.748 \%$ respectively in both seasons) followed by soil application at 4 $m g \mathrm{~L}^{-1}(2.661 \%)$ during the first season andby foliar application at $4 \mathrm{mg} \mathrm{L}^{-1}(2.549 \%)$ during the second season. Plants sprayed with KI at 2 $\mathrm{mg} \mathrm{L}^{-1}$ had lowest nitrogen content during the first season. The phosphorus and potassium contents in pelargonium shoots were varied in response to KI application methods. Soil application method at $6 \mathrm{mg} \mathrm{L}^{-1}$ significantly led to highly increasing the $\mathrm{P} \%$ concentration during the both seasons. The potassium content in plant shoots 
TABLE 5. Nitrogen, phosphorus and potassium contents inPelargonium $\times$ hortorumas affected by different application methods and concentrationsof potassium iodide (KI) during the two seasons (2017 and 2018).

\begin{tabular}{|c|c|c|c|c|c|c|}
\hline \multirow{2}{*}{ Treatments } & \multicolumn{2}{|c|}{$\mathbf{N} \%$} & \multicolumn{2}{|c|}{$\mathbf{P} \%$} & \multicolumn{2}{|c|}{ K \% } \\
\hline & $1^{\text {st }}$ season & $2^{\text {nd }}$ season & $1^{\text {st }}$ season & $2^{\text {nd }}$ season & $1^{\text {st }}$ season & $2^{\text {nd }}$ season \\
\hline Control & $2.220 \mathrm{i}$ & $2.285 \mathrm{~h}$ & $0.321 \mathrm{~g}$ & $0.330 \mathrm{~h}$ & $2.494 \mathrm{c}$ & $2.458 b$ \\
\hline Foliar application at $2 \mathrm{mg} \mathrm{L}^{-1}$ & 2.0361 & $2.213 \mathrm{j}$ & $0.333 \mathrm{e}$ & $0.362 b$ & $2.056 \mathrm{k}$ & $2.041 \mathrm{i}$ \\
\hline Foliar application at $4 \mathrm{mg} \mathrm{L}^{-1}$ & $2.218 \mathrm{j}$ & $2.549 \mathrm{~b}$ & $0.330 \mathrm{f}$ & $0.342 \mathrm{e}$ & $2.076 \mathrm{j}$ & $2.043 \mathrm{i}$ \\
\hline Foliar application at $6 \mathrm{mg} \mathrm{L}^{-1}$ & $2.709 \mathrm{a}$ & $2.748 \mathrm{a}$ & 0.2581 & $0.260 \mathrm{j}$ & $2.122 \mathrm{~h}$ & $2.015 \mathrm{j}$ \\
\hline Foliar application at $8 \mathrm{mg} \mathrm{L}^{-1}$ & $2.618 \mathrm{c}$ & $2.411 \mathrm{~d}$ & $0.314 \mathrm{~h}$ & $0.338 \mathrm{f}$ & $2.316 \mathrm{e}$ & $2.287 \mathrm{~d}$ \\
\hline Soil application at $2 \mathrm{mg} \mathrm{L}^{-1}$ & $2.590 \mathrm{~d}$ & $2.250 \mathrm{i}$ & $0.342 \mathrm{c}$ & $0.331 \mathrm{~h}$ & $2.291 \mathrm{f}$ & $2.139 \mathrm{f}$ \\
\hline Soil application at $4 \mathrm{mg} \mathrm{L}^{-1}$ & $2.661 \mathrm{~b}$ & $2.301 \mathrm{~g}$ & $0.360 \mathrm{~b}$ & $0.384 \mathrm{a}$ & $2.772 \mathrm{a}$ & $2.596 \mathrm{a}$ \\
\hline Soil application at $6 \mathrm{mg} \mathrm{L}^{-1}$ & $2.423 \mathrm{~h}$ & $2.340 \mathrm{f}$ & $0.364 \mathrm{a}$ & $0.357 \mathrm{c}$ & $2.579 \mathrm{~b}$ & $2.213 \mathrm{e}$ \\
\hline Soil application at $8 \mathrm{mg} \mathrm{L}^{-1}$ & $2.493 \mathrm{f}$ & $2.509 \mathrm{c}$ & $0.289 \mathrm{k}$ & $0.219 \mathrm{k}$ & $2.092 \mathrm{i}$ & $2.057 \mathrm{~h}$ \\
\hline Foliar + soil at $2 \mathrm{mg} \mathrm{L}^{-1}$ & $2.576 \mathrm{e}$ & $2.508 \mathrm{c}$ & $0.308 \mathrm{i}$ & $0.288 \mathrm{i}$ & $1.885 \mathrm{~m}$ & 1.6441 \\
\hline Foliar + soil at $4 \mathrm{mg} \mathrm{L}^{-1}$ & $2.433 \mathrm{~g}$ & $2.245 \mathrm{i}$ & $0.336 \mathrm{~d}$ & $0.341 \mathrm{e}$ & $2.142 \mathrm{~g}$ & $2.108 \mathrm{~g}$ \\
\hline Foliar + soil at $6 \mathrm{mg} \mathrm{L}^{-1}$ & $2.235 \mathrm{i}$ & $2.369 \mathrm{e}$ & $0.320 \mathrm{~g}$ & $0.335 \mathrm{~g}$ & $2.424 \mathrm{~d}$ & $2.308 \mathrm{c}$ \\
\hline Foliar + soil at $8 \mathrm{mg} \mathrm{L}^{-1}$ & $2.097 \mathrm{k}$ & $2.117 \mathrm{k}$ & $0.305 \mathrm{j}$ & $0.350 \mathrm{~d}$ & 1.9261 & $1.884 \mathrm{k}$ \\
\hline
\end{tabular}

Mean values followed by the same letter in each column do not differ significantly at $\mathrm{P} \leq 0.05$ based on Duncan's multiple range test.

significantly increased by soil application with $\mathrm{KI}$ at $4 \mathrm{mg} \mathrm{L}^{-1}$ during the both seasons $(2.772 \%$ \& $2.596 \%$ respectively). Particularly interesting is the fact that spraying method with $\mathrm{KI}$ at $2 \mathrm{mg}$ $\mathrm{L}^{-1}$ diminished the NPK content of pelargonium plants.

Effects of KI applications on total sugar contents

Total sugars were significantly influenced by the treatment of KI during both seasons (Fig. 1). Soil application of KI at 2, 4 and $6 \mathrm{mg}$ $\mathrm{L}^{-1}$ significantly gave the highest values of total sugars comparing with the other application methods. Also, thetotal sugars contents increasedwhen sprayingplants either with 6 or $8 \mathrm{mg} \mathrm{L}^{-1}$ concentration in comparison to control plants.Plants treated by soil application combined with spraying plants with $\mathrm{KI}$ at $4 \mathrm{mg} \mathrm{L}^{-1}$ led to reduce the total sugar contents.

Effects of KI applications on total poly-phenols contents

Total poly-phenol compounds along all treatments were decreased comparing with the control plants during the two seasons (Fig. 2). In comparison between the three methods 


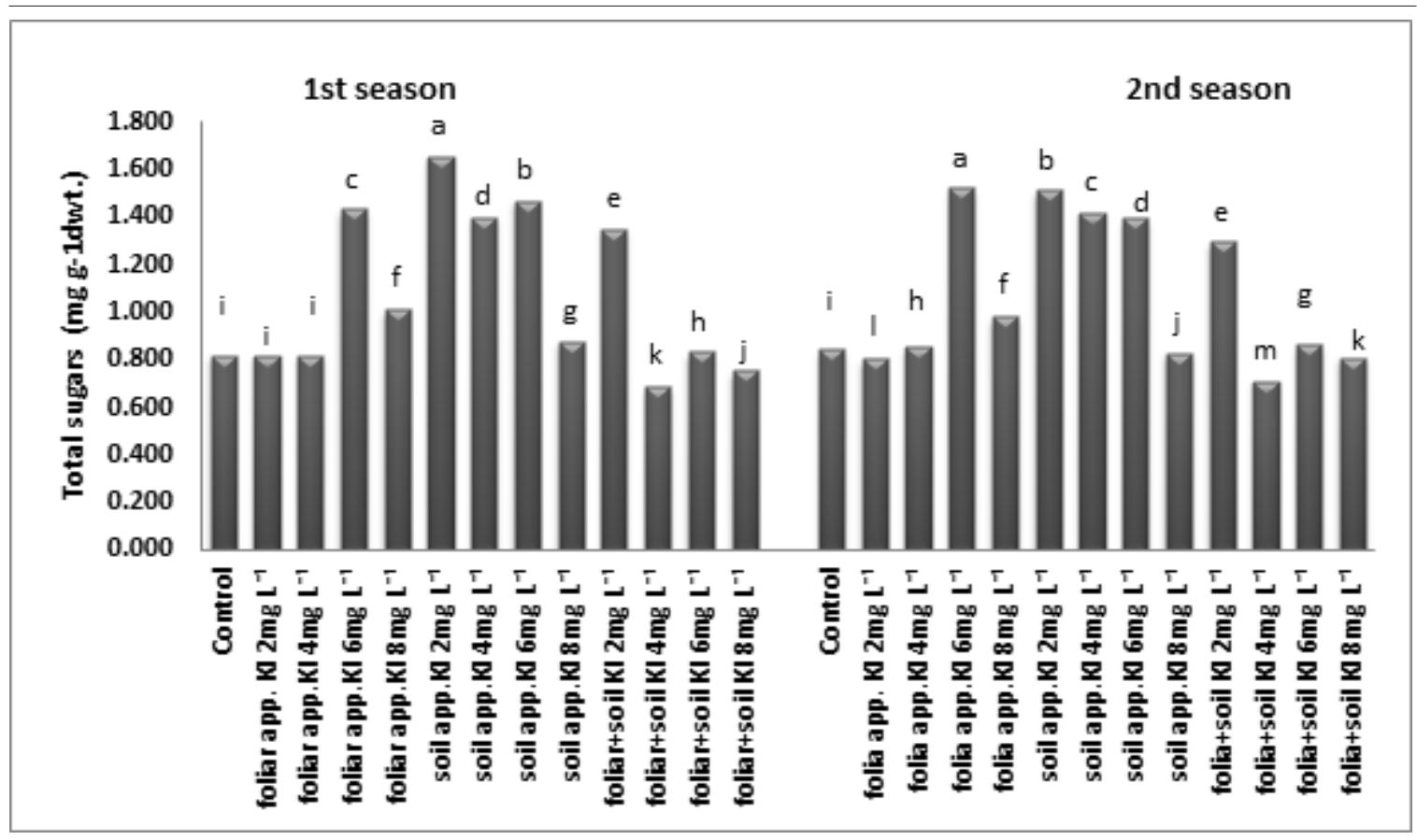

Mean values followed by the same letter in each season do not differ significantly at $\mathrm{P} \leq 0.05$ based on Duncan's multiple range test.

Fig. 1. Total sugars content (mg g-1dwt.) in Pelargonium $\times$ hortorumas affected by different application methods and concentrations of potassium iodide (KI) during the two seasons (2017 and 2018).

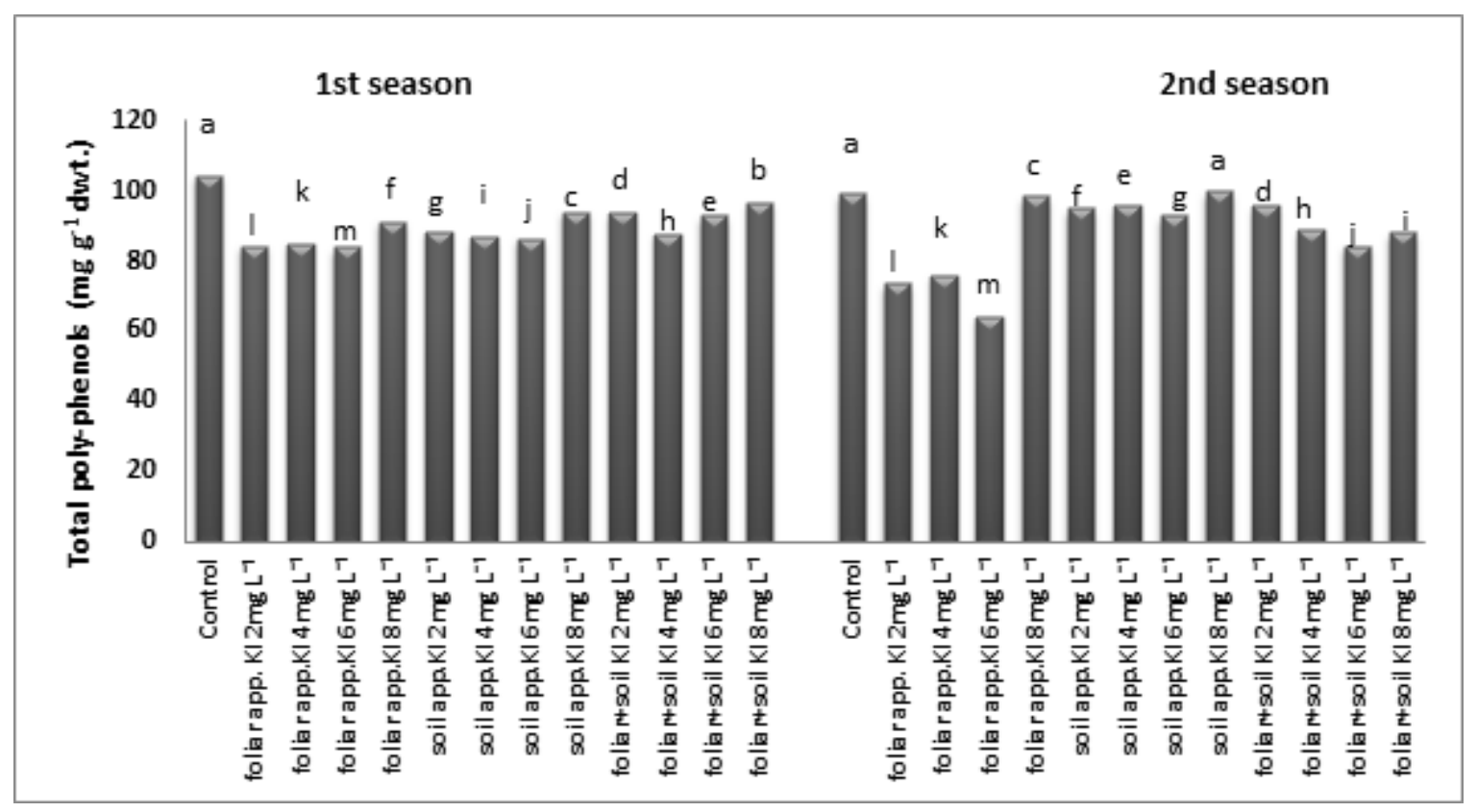

Mean values followed by the same letter in each season do not differ significantly at $\mathrm{P} \leq 0.05$ based on Duncan's multiple range test.

Fig. 2. Total poly-phenols content inPelargonium $\times$ hortorum as affected by different application methods and concentrations. 
of applications, the soil combined with foliar application treatment at $8 \mathrm{mg} \mathrm{L}^{-1}$ recorded the highest value of phenols (96.69mg $\mathrm{g}^{-1} \mathrm{dwt}$.) during the first season while soil application at $8 \mathrm{mg} \mathrm{L}^{-1}$ gave the highest content of poly-phenols (99.84 $\mathrm{mg} \mathrm{g}^{-1} \mathrm{dwt}$.) during the second season.

\section{Discussion}

The present investigation demonstrated that KI nutrition had mostly positive effects on the pelargonium vegetative growth and physiological parameters. The trials presented here clearly indicated that the shoot length, number of branches and fresh and dry weights as well as the inflorescence characterize were much greater with the soil application method than the foliar application. Accordantly to the previous results obtained in the biofortification with $\mathrm{KI}$, the growth of some plants (e.g. perennial ryegrass, tomatoes, spinach) was significantly activated by iodine application to the growth environment (Borst Pauwels, 1961). Also, the results acquired in this investigation would be in conformity with the previous results on some vegetable species (i.e. Landini et al., 2011 on tomato and Lawson et al., 2015 on lettuce). Biofortification had more effectiveness with increasing iodine doses (Blasco et al. 2008 and Weng et al. 2008). In agreement with that, the results obtained from this investigation indicated that pelargonium plants have an adverse response in the growth and inflorescence parameters when sprayed with $\mathrm{KI}$ at the lowest concentration $\left(2 \mathrm{mg} \mathrm{L}^{-1}\right)$. Concerning the influence of KI on increasing the plant biomass of this investigation,it may be attributed to the impact of KI on nitrogen absorption and metabolism in plants. The increasing ofN, $\mathrm{P}$, and $\mathrm{K}$ concentrations in pelargonium plants obtained in this study may be attributed to the influence of KI on increasing the easily soluble forms of these elements in soil (Smolen et al. 2011) and this observation can indirectly induced a positive effects of iodine in improved plant growth and yielding (KabataPendias and Mukherjee, 2007). Smolen and sady (2011a) stated that the soil application of iodine contributed to increase the nitrogen mineral (N$\mathrm{NO}_{3}$ ) level in soil what was moreover reflected in improved nitrogen nutrition of spinach. They added that biofortification with KI may enhanced the growth and development of microorganisms responsible for mineralization of soil organic matter, resulted in increasing the amount of mineral nitrogen released in this process and

Egypt. J. Hort. Vol. 46, No.1 (2019) improved the nitrogen uptake by plants as well as increasing the nitrogen-utilization efficiency (Blasco et al. 2011). Iodine in general affects nitrogen metabolism in plants. Nevertheless, iodine impact on macronutrients uptake by plants depends on many factors, including: iodine form, dose and method of application and also it affected by conditions of crop cultivation and genotypic variation of plants in the ability towards particular speciation of elements taken from soil (Smolen and Sady, 2011b).

The results obtained from this investigation clearly indicated that KI resulted to a relatively increasing the total sugars and decreasing the total phenols in all treated planted. Smolen and sady (2011a) stated that iodine significantly did not affect the level of phenolic compounds in spinach. In contrary, Blasco et al.(2008) reported an increasing in accumulation of phenols and ascorbic acid, as well as antioxidant potential with KI treatments in lettuce grown in hydroponics.

Concerning to the adverse responses in all parameters of pelargonium plants which treated with the highest concentration of KI $\left(8 \mathrm{mg} \mathrm{L}^{-1}\right)$ as foliar combined with ground applications may be attributed to the toxic effects of KI on plants. Singh et al. (2012) stated that higher concentration of KI led to drastically decrease the plant height of rice. Lawson et al. (2015) reported that the phytotoxic symptoms on older leaves of lettuce were observed in the very early developmental stage when the highest KI dose was applied and they were indicated to their little known about the mechanism of iodide toxicity in plants. However, Mynett and Wain (1973) reported that KI may arise from intracellular oxidation of iodide to elemental iodine followed by iodination of cellular components, including chlorophyll.

\section{Conclusion}

Generally, the results obtained from this investigation reveal that KI application enhanced the vegetative growth and flowering characters and some physiological parameters except total phenolic compounds of pelargonium plants when it applied as soil application at all tested concentrations $\left(2,4,6\right.$ and $\left.8 \mathrm{mg} \mathrm{L}^{-1}\right)$ and also when applied as foliar application at 6 and $8 \mathrm{mg}$ $\mathrm{L}^{-1}$. Certainly, the soil application of KI has the advantage for increasing the nutrients availability and efficiency use of the pelargonium plants and will be a good idea for the promotion of plant growth criteria in sustainable agricultural 
production systems especially on the times of the extremely high nutrients cost. However, the recommendation of the suggested idea to the iodine fertilization needs further studies to trace the effects of KI application on the ornamental plant growth.

\section{Acknowledgment}

No acknowledgments were announced.

\section{Funding statements}

No external funding was received for this study

\section{Conflicts of interest}

No conflicts of interest to declare.

\section{References}

AOAC. (1990) Official Methods of the Analytical Chemist, $15^{\text {th }}$ ed., Vol.2., Association of Official Analytical Chemists (A.O.A.C.), Arlington, Virginia, USA.

Blasco, B., Rios, J.J, Cervilla, L.M., Sá nchez-Rodrigez, E., Ruiz, J.M. and Romero, L. (2008) Iodine biofortification and antioxidant capacity of lettuce: potential benefits for cultivation and human health. Ann. Appl. Biol., 152, 289-299.

Blasco, B., Rios, J.J, Cervilla, L.M., Sá nchezRodrigez, E., Rubio-Wilhelmi, M. M.,Rosales, M. A., Romero, L. and Ruiz, J. M. (2011) Iodine application affects nitrogen use efficiency of lettuce plants (Lactuca sativa L.). Acta Agriculturae Scandinavica, Section B - Soil \& Plant Science Vol. 61, Iss. 4.

Borst Pauwels, G.W.F.H. (1961) Iodine as a micronutrient for plants. Plant Soil, 14, 377-392.

Dewis, J. and Fertias, F. (1970) Physical and chemical methods of soil and water analysis. Soils Bulletin No. 10. Rome, FAO, [accessed 2015 Oct. 21].ttp:// www.fao.org/docrep/017/a2060e/a2060e.pdf.

Dubios, M., Gilles, K.A., Hamilton, J.K., Robers, P.A. and Smith, F. (1956) Colorimetric method for determination of sugars and related substances. Analytical Chem., 28, 350-356. Calcutta, pp. 342.

Flora Holland, Facts \& Figures (2017) https://www. royalfloraholland.com/media/12324292/royalfloraholland-annual-report-2017-en.pdf

Fuge, R. and Johnson, C.C. (2015) Iodine and human health, the roleenvironmental geochemistry and diet, a review. Appl. Geochem., 63, 282-302. doi:10.1016/japgeochem. 2015.09.013
Gomez, K.A. and Gomez, A.A. (1984) Statistical Procedures for Agriculture Research, John Wiley and Sons, Inc, New York.

Jackson, M.L. (1967) Soil Chemical Analysis, PrenticeHall, India, 144-197.

Jopke, P., Bahadir, M., Fleckenstein, F. and Schnug, E. (1996).Iodine determinationin plant materials. Commun. Soil Sci. Plant Anal., 27,741-751.

Kabata-Pendias, A. and Mukherjee, A. B. (2007).Trace Elements from Soil toHuman.Springer-Verlag, Berlin Heidelberg, pp. 442-447.

Lawson, P.G., Daum, D., Czauderna, R., Meuser, H. and Härtling, J.W. (2015).Soilversus foliar iodine fertilization as a biofortification strategy for field grownvegetables. Front. Plant Sci., 6, 450.

Li, H., Cheng, K.,Wong, C., Fan, K., Chen, F. and Jiang, Y. (2007). Evaluation of antioxidant capacity and total phenolic content of different fractions of selected microalgae. Food Chem., 102, 771-776.

Lichtenthaler, H.K. and Wellburn, A.R. (1983) Determinations of total carotenoids and chlorophylls $\mathrm{a}$ and $\mathrm{b}$ in leaf extracts in different solvents. Biochem. Soc. Trans. 11, 591-592.

Landini, M., Gonzali, S., and Perata, P. (2011) Iodine biofortification in tomato. J. Plant Nutr. Soil Sci., 174, 480-486.

Medrano-Macías, J., Leija-Martínez, P.,GonzálezMorales, S., Juárez-Maldonado, A. and BenavidesMendoza, A. (2016) Use of Iodine to Biofortify andPromote Growth and Stress Tolerance in Crops. Front. Plant Sci., 7, 1146. doi: 10.3389/ fpls.2016.01146

Moreda-Piñeiro, A., Romarís-Hortas, V. and BermejoBarrera, P. (2011) A reviewon iodine speciation for environmental, biological and nutrition fields.J. Anal.At. Spectrom. 26, 2107-2152. doi:10.1039/ C0JA00272K

Muramatsu, Y. and Yoshida, S. (1999) Effects of microorganisms on the fate ofiodine in the soil environment. Geomicrobiol. J. 16, 85-93. doi:10.1080/014904599270776

Mynett, A. and Wain, R. L. (1973) Herbicidal action of iodide: effect onchlorophyll content and photosynthesis in dwarf bean Phaseolus vulgaris. Weed Res., 13, 101-109. doi:10.1111/j.13653180.1973.tb01250. 
Olsen, S.R. and Sommer, L.E. (1982) Determination of available phosphorus. In: Page,A. L., Miller, R.H., and Keeney, D.R., "Method of Soil Analysis", $2^{\text {nd }}$ ed., 403-440. Agronomy Series No.9, Part 2. Soil Science Society of America, Inc., Madison, WI.

Richards, L.A. (1954) Agriculture Handbook, Diagnosis and improving of saline and alkaline soils. U.S.,Salinity Laboratory Staff No.60.

Saunders R.W., Kumar R., MacDonald S.M. and Plane J.M.C. (2012) Insights into the photochemical transformation of iodine in aqueous systems:humic acid photosensitized reduction of iodate. Environ. Sci. Technol., 46, 11854-11861. doi:10.1021/ es3030935

Singh, A.K., Singh, A., Singh, A.K., Shamim, M., Vikram, P., Singh, S. and Chaturvedi, G. (2012) Application of potassiumiodide as a new agent for screening of drought tolerance upland ricegenotypes at flowering stage. P. Kn. J., 1 (1), 25-32.

Smoleń, S. and Sady, W. (2011a) Influence of iodine fertilization and soilapplication of sucrose on the effectiveness of iodine biofortification, yield,nitrogen metabolism and biological quality of spinach. Acta Sci. Pol., Hortorum Cultus, 10 (4), 51-63.

Smoleń, S. and Sady, W. (2011b) Effect of iodine fertilization and soil applicationof sucrose on the content of selected heavy metals and trace elements inspinach. Acta Sci. Pol., HortorumCultus, 10 (4), 37-50.
Smoleń, S., Sady, W., Rożek, S., Ledwożyw-Smoleń, I. and Strzetelski, P.(2011) Preliminary evaluation of the influence of iodine and nitrogenfertilization on the effectiveness of iodine biofortification and mineralcomposition of carrot storage roots. $J$. Elem., 16 (2), 275-285.

Venturi, S. (2011) Evolutionary significance of iodine. Curr. Chem. Biol., 5, 155-162. doi:10.2174/2212796811105030155

Voogt, W., Holwerda, H. T. and Khodabaks, R., (2010) Biofortification of lettuce (Lactuca sativa $\mathrm{L}$.) with iodine: the effect of iodine form and concentration inthe nutrient solution on growth, development and iodine uptake of lettucegrown in water culture. $J$. Sci. Food Agric., 90, 906-913.

Weng, H.X., Yan, A.L., Hong, C.L., Xie, L.L., Qin, Y.C. and Cheng, C.Q. (2008) Uptake of different species of iodine by water spinach and its effect to growth. Biol. Trace Elem. Res., 124, 184-194.

Whitehead, D. C. (1973) Uptake and distribution of iodine in grass and cloverplants grown in solution culture. J. Sci. Food Agric., 24, 43-50.

(Received 25/02/2019; accepted 07/04/2019) 


\section{تحسين إنتاج وجودة نباتات الجارونيا باستخدام يوديد البوتاسيوم}

نعيمه اسماعيل السبا

قسم بحوث نباتات الزينة وتنسيق الحدائق ـ معهد بحوث البساتينـ مركز البحوث الزر اعية ـ القاهرة ـ مصر.

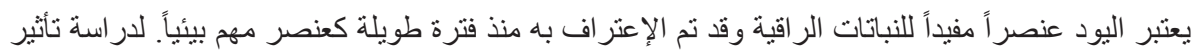

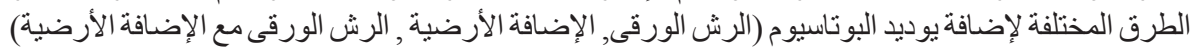

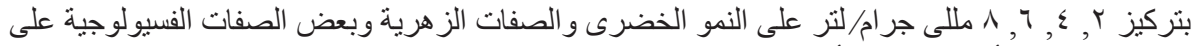

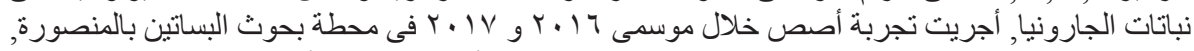

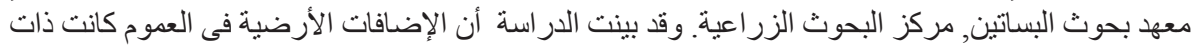

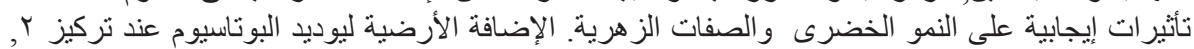

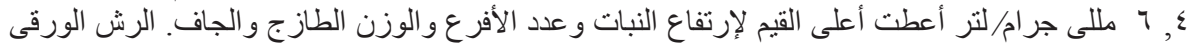

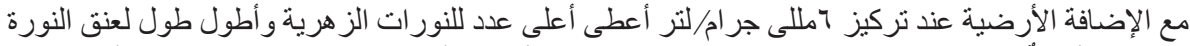

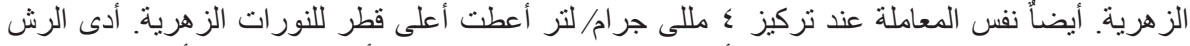

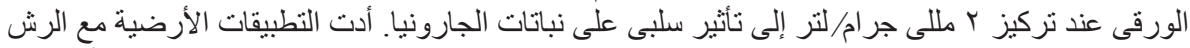

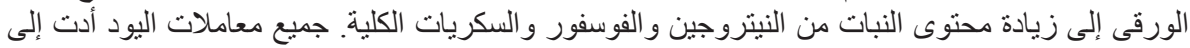

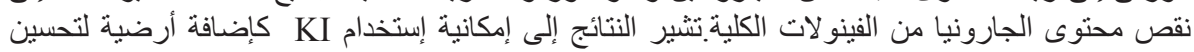
إنتاجية وجودة نباتات الجارونيا. 